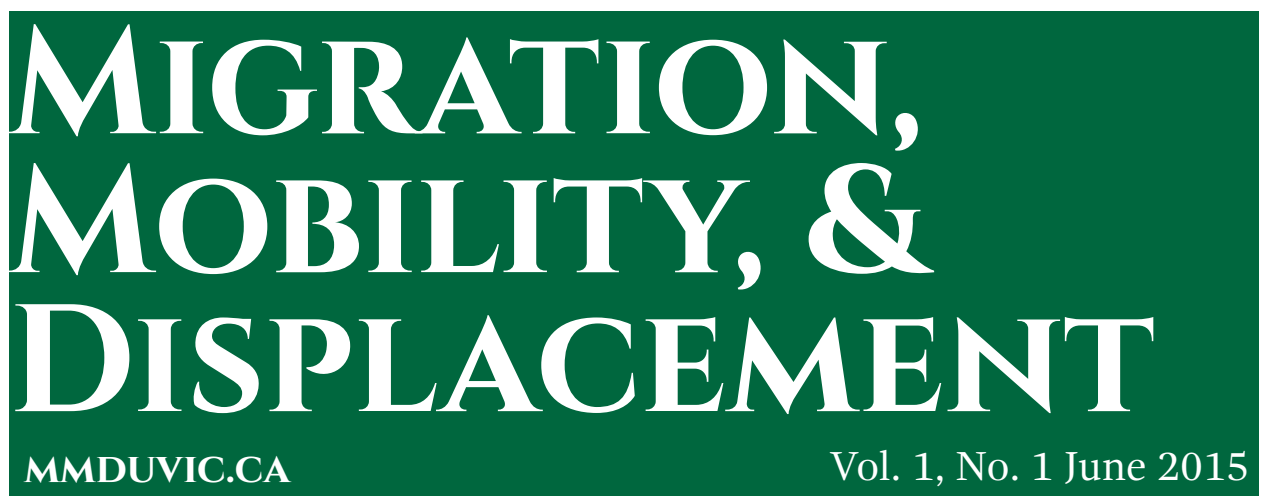

Chen, Xiaobei and Sherry Xiaohan Thorpe. 2015. “Temporary Families? the Parent and Grandparent Sponsorship Program and the Neoliberal Regime of Immigration Governance in Canada." Migration, Mobility, \& Displacement. 1 (1): 81-98.

Migration, Mobility \& Displacement is an online, open-access, peer-reviewed journal. It seeks to publish original and innovative scholarly articles, juried thematic essays from migrant advocacy groups and practitioners, and visual essays that speak to migration, mobility and displacement and that relate in diverse ways to the Asia-Pacific. The journal welcomes submissions from scholars and migrant advocacy groups that are publicly engaged, and who seek to address a range of issues facing migrants, mobile and displaced persons, and especially work which explores injustices and inequalities.

We welcome submissions and inquiries from prosepctive authors. Please visit our website mmduvic.ca, or contact the editor for more information.

EDITOR-IN-CHIEF

Dr. Feng Xu

mmded@uvic.ca

PUBLISHED BY

The Centre for Asia-Pacific Initiatives

University of Victoria

3800 Finnerty Road, Victoria, BC, V8P 5C2, Canada

uvic.capi.ca

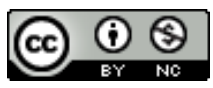

Licenced under Creative Commons

Attribution-NonCommercial 4.0 International.

creativecommons.org/licenses/by-nc/4.0/
TECHNICAL EDITOR

Joel Legassie mmpcapi@uvic.ca 


\title{
TEMPORARY FAMILIES? THE PARENT AND GRANDPARENT SPONSORSHIP PROGRAM AND THE NEOLIBERAL REGIME OF IMMIGRATION GOVERNANCE IN CANADA'
}

\author{
XIAOBEI CHEN \\ SHERRY XIAOHAN THORPE
}

\begin{abstract}
The Canadian government has introduced a series of policy changes to various immigration programs since 2008. This paper focuses on the revamping of the parent and grandparent (PGP) sponsorship program and the introduction of new measures such as the Super Visa. Using Foucauldian analytical tools and drawing on Bacchi's $(2009,2012)$ method of studying policy as problematizations, we first historicize the problematization of the family in immigration policy. Second, we refute the government's representation of immigration under the PGP program problems as essentially a transparent "problem of math," that of too many applicants overwhelming the system. Finally, we analyze neoliberal technologies of immigration governance and their impact on citizenship formation and struggles. Who counts as family, we argue, has been biopolitically determined in Canadian immigration policy. Family members are recognized as such when it suits the needs of the state. The latest changes in family sponsorship policies objectify potential parents and grandparents reunification applicants, seeing them as human liabilities that pose risks to the Canadian population because of their advanced age. The new measures deploy a neoliberal regime of governance that discriminatorily responsibilizes the family, marketizes regulation, and maximizes the state's control of the border and of the population.
\end{abstract}

The parent and grandparent (PGP) sponsorship program in Family Class immigration hardly ever registers in the contentious politics of migration and remains a significantly under-examined area in contemporary migration and diaspora studies. Yet important changes were made to the program in the last few years that raise questions about immigration policy's impact on the equality of citizenship in Canada and reveal characteristics of a neoliberal regime of immigration governance. This paper thus contributes to critical analyses of neoliberal immigration governance in the twenty-first century.

On November 4, 2011, Jason Kenney, then Minister of Citizenship, Immigration and Multiculturalism, announced the first phase of the Action Plan for Faster

\footnotetext{
${ }^{1}$ An earlier version of this paper has been presented at Canadian Sociological Association Annual Conference, Victoria, June 3-8, 2013. Our sincere thanks to Elizabeth Paradis for her very helpful assistance. We thank the editor and two anonymous reviewers for their constructive and helpful comments.
} 
Family Reunification. It consisted of a series of measures to revamp the PGP program, which allows Canadian citizens and permanent residents to reunite with their overseas parents and grandparents by sponsoring them to come to Canada as permanent residents. The PGP program has been confronted with two persisting challenges since the mid-1990s: a growing application backlog and an excessively lengthy processing time. At a news conference, Kenney drew attention to a backlog of 165,000 applications, and revealed that PGP program applicants had to wait six years on average for a final decision on their applications. The objectives of Phase I of the Action Plan were, he stated, "to cut the backlog, to speed up processing times and to make it easier for parents to visit" (CIC 2011a). By way of implementing top-down ministerial instructions (Alboim and Cohl 2012; Boyd 2014; Neborak 2014), the measures taken included first, placing a two-year moratorium on incoming PGP sponsorship applications to prevent the backlog from growing; second, increasing the number of parents and grandparents admitted as permanent residents from nearly 15,500 in 2010 to 25,000 in 2012; third, launching a ten-year multiple-entry Super Visa that would allow eligible applicants to come to Canada as visitors; and fourth, holding national consultations on redesigning the PGP program to ensure that large backlogs would not occur in the future and that the redesigned program would be "sensitive to Canada's fiscal constraints," to use the government's language (CIC 2011a).

The increase in the quota in 2012 and 2013 resulted in 50,000 parents and grandparents being admitted to Canada, which helped reduce the backlog significantly. This was a long overdue relief for many families who had been stuck in the massive backlog for years. Yet the moratorium, together with the Super Visa, sent worrisome signals about the future of the PGP program (Canadian Council for Refugees 2012; Ontario Council of Agencies Serving Immigrants 2012). In May 2013, the Canadian government announced the objectives of Phase II of the Action Plan, which included the permanency of the Super Visa, as well as a 30 percent increase in the minimum income necessary for sponsorship applicants, who were, moreover, required to demonstrate their income level for three years (up from one year) and to extend the sponsorship undertaking period to twenty years instead of ten. New applications started to be accepted in 2014, but capped at only 5,000 (CIC 2013b).

These changes constitute a significant part of a Canadian immigration policy shift since the Conservative Party came to power in 2006. As observers of skilled immigrants and temporary foreign workers programs have pointed out, this shift is characterized by centralized policy-making and a preoccupation with market demand and employment (Fudge and McPhail 2009; Alboim and Cohl 2012; Boyd and Alboim 2012; Boyd 2014; Neborak 2014). Neoliberal concerns and aspirations, which led to tighter restrictions on the eligibility of skilled immigrants and the growing use of temporary foreign workers, have similarly driven the delegitimatizing of elderly family members as immigrants to Canada. A critical examination of the drastic changes to the PGP program further sheds light on the formation of a neoliberal regime of immigration governance that extends 
market-based regulation, maximizes the state's control of the border and the population, admits migrants on the basis of their economic contributions, and, in the case of the PGP program, severely restricts the immigration of people who are seen as economic burdens, moreover, changes to the PGP sponsorship possibilities have social and policy-related implications to the Asia-Pacific region in terms of immigration patterns and transnational elderly care. Since the introduction of a skill- and education-based immigration points system in 1967, the Asia-Pacific region has replaced Europe as the main source of migrants to Canada. In 2013, the top three source countries were China (accounting for 13.2 percent of new landed permanent residents that year), India (12.8 per cent), and the Philippines (11.5 per cent); in the same year the Asia-Pacific region accounted for 55.7 percent of Family Class immigrants. Over the past decade, on average, about one third of Family Class immigrants were sponsored parents and grandparents (CIC 2015). As a result, restrictions applied to the PGP program affect Canadian families of Asia-Pacific origin the most, many of whom will now be unable to be reunited with their parents and grandparents.

Immigration policy is a pillar of biopolitical governance, defined by calculated, rational activities that employ certain knowledges and techniques for definitive though shifting ends (Dean 1999); it constitutes biopolitics in that the very notion of immigration as an object of governance is premised on an awareness of a population and a deliberate consideration of a population's racial, ethnic, sexual, reproductive, labor skill sets, and other characteristics (Foucault 2003). For the state, to make immigration policy is to devise interventions to bring in "the right people." These policies aim to preserve, improve, and sometimes, to transform certain characteristics of the Canadian population, or to keep out enemies that could conceivably menace the well-being of the population (Walters 2002; Chen 2008). The admission of immigrants to Canada has always been fundamentally imagined as a solution to economic challenges identified in Canadian society. As such, various versions of human capital discourse have been central to immigration policy (Li 2003, 2004; Abu-Laban and Gabriel 2003; McLaren and Black 2005; McLaren 2006; Fudge and McPhail 2009).

The concept of family reunification appeared in immigration policy as early as 1908 (DeShaw 2006), though different opinions exist about its rationality. Some attribute it to compassion and humanitarianism (Ley and Hiebert 2001; Daniel 2005), while others are adamant that family reunification is based on the value Canada accords to family relationships (DeShaw 2006, 9). Regardless, as we demonstrate in the following, the legitimacy of family reunification has been mediated by economic concerns of the nation and moreover, the definition of "family" has shifted in response to economic conditions and perceived national population needs. The latest changes to the category of Family Class reflects a persistent adherence to an ever-modified idea about the human capital in immigration policy, whereby parents and grandparents are explicitly objectified as what we would term "human liabilities" (the opposite of human capital), and are seen as posing risks to the Canadian population because of their advanced age (Chen 2008). 
In what follows, we first contextualize the problematization of the PGP program by examining what has been seen as the "problem" (Bacchi 2009, 2012) in the history of family reunification immigration in Canada. Second, we refute the Canadian government's representation of the trouble with the PGP program as a problem of math: a problem of too many applicants overwhelming the system. We argue that the current biopolitical construction of the ideal immigrant objectifies parents and grandparents as human liabilities unwanted in Canada, and their children and grandchildren as desirable human capital. Third, we discuss the technologies of a neoliberal regime of government that frees the state from responsibilities while simultaneously increasing its control (Dean 2014). The section on family reunification in Canadian immigration history is based on key government documents: the 1966 White Paper on Immigration, the 1974 Green Paper on Immigration, and selected sections of House of Commons Debates concerning these two Papers (House of Commons Standing Committee on Labour, Manpower and Immigration 1977). Analysis of recent changes to the PGP program is mainly based on government policy statements, news releases, community organizations' responses, and the media coverage $(2005,2015)$. While the data is limited in documenting the actual impact of the reform on immigrant families, we believe they provide ample material for analyzing the shifting rationalities and technologies in the PGP program.

\section{HiSTORICIZING THE PROBLEM(S) OF FAMILY REUNIFICATION}

In this section, we discuss the circumstances under which the Family Class first emerged in Canadian immigration history and the implications of this categorization for governing sponsored immigration then and now.

\section{Separation of Dependents from Non-dependents}

In the aftermath of World War II, in response to the rising crisis of displaced persons, the Canadian government "cautiously opened up categories for the admission of relatives in spite of the country's restrictive immigration program" (Daniel 2005, 684). Since then, Canada has been emphatic about its fundamental commitment to family reunification. For about two decades until 1967, there were two general categories of immigrants to Canada: unsponsored and sponsored. Unsponsored immigrants had to go through a selection process that, prior to 1962, was based on nationality, and later on education, training and skills (St. John-Jones 1973). Sponsored immigrants were not subjected to such a selection process. They were eligible to come because they had relatives in Canada willing to help them. In the years immediately following World War II, the sponsorship system was viewed positively by government officials because they believed that having a relative present in Canada would ease a newcomer's settlement. Between 1946 and 1966 more than 2,500,000 immigrants were admitted, of whom 900,000 were sponsored, with the largest number originating from Italy, Portugal, and

\footnotetext{
2 There were restrictions during the immediate postwar period (1946-57) on admissible immigrants under an order-in-council of March 31, 1931. For a detailed discussion, see Hawkins (1972, 90).
} 
Greece. Statistics from 1962 onward revealed that almost half of the total number of sponsored immigrants were distant relatives, only a small percentage of whom could have qualified under the unsponsored or skilled immigrant program.

In the late 1960s and early 1970s, questions started to be raised about the sponsored immigration. The view was that as Canada was becoming "a highly complex industrialized and urbanized society" demanding a highly skilled work force (Department of Manpower and Immigration 1966), the possibility of an "explosive" influx of unskilled immigrants was undesirable. Hawkins, for example, stated that "The first [problem] simply was that it escalated - and in an alarming way. By the mid-fifties it was calculated that one Italian immigrant meant fortynine Italian relatives, and the potential for family sponsorship was even higher. The second problem was that the essential base of the [sponsored] movement was the unskilled, often nearly illiterate, manual labourer[s] from southern Europe, emigrating or recruited in the first few years after the war" (Hawkins 1972, 51).

To address this problem, the 1966 White Paper proposed two restrictive measures. The first was to divide the sponsored category into two groups: sponsored dependents (the "true dependents"), and non-dependent relatives (or nominated relatives). This measure was to ensure that only the first group could be admitted regardless of education and skill levels. Using dependence between relatives as the criterion for defining family was supposed to be a measurable and colourblind approach that would avoid any controversies posed by cultural differences. Recognizing that "we cannot expect to bring workers to Canada without also welcoming their dependents," the White Paper specified that "the family ... normally means wife and children, but dependents may also be elderly parents or grandparents, or they may be younger relatives who are orphaned" (Department of Manpower and Immigration 1966, 13). It emphasized that the dependents of skilled immigrants admitted to Canada were not part of the problem with chain migration; but rather, it was the influx of non-dependent relatives entering Canada without meeting the education and skills requirements that needed to be kept in check. By 1967, the non-dependent applicants, or nominated relatives, were subjected partially to the newly created points system. Having a Canadian citizen as a relative gave non-dependent applicants a slight advantage (Hawkins 1972).

\section{The Birth of Family Class}

Over several years following the establishment of the points system, it was noted that despite the new measures, the average skill level among newcomers was significantly declining. For this, the Green Paper laid blame on the nominated relative class, claiming that overall nominated relatives were less skilled than other groups of immigrants and had more difficulty integrating into the labour market (Department of Manpower and Immigration 1974). Their immigration was condemned as "simultaneously inefficient at the economic level and unjustified at the family level" (House of Commons Standing Committee on Labour, Manpower and Immigration 1977). "To guarantee the most effective 
linkage possible between manpower and immigration policies," the Green Paper recommended eliminating the nominated, non-dependent class. This proposal was met with fierce opposition from immigrant communities as well as from civil rights and humanitarian organizations, churches, the New Democratic Party, and some MPs (Daniel 2005, 693), who defended the nominated category on a number of grounds: the importance of the extended family in many cultures, the need to guard against discrimination, and the concept of migration as a right, and refuted the charge that nominated immigrants would not succeed in integrating. In the end, the Immigration Act of 1976 disassociated the immigration of nominated relatives from the notion of family reunification, through installing three classes of immigrants: Family Class, refugees, and other applicants. Family Class immigrants included immediate family members and parents and grandparents over sixty years of age. The other applicants category included independent immigrants and "assisted relatives," a new term for nominated relatives. The new category 'Family Class' indicated a conscious decision on the part of the government to explicitly define who should be considered as family in terms of eligibility for family reunification immigration.

Evidently in the 1960s and 1970s, the primary subjects of problematization were those defined by the Canadian state as distant relatives, including aunts, uncles, nieces and nephews and even adult siblings. By contrast, immediate family and elderly parents and grandparents seemed to have occupied an unquestionable legitimacy in the political project of family reunification. Dependents, such as spouses, children, parents and grandparents were consistently regarded as the rightful candidates for family reunification. The Green Paper stated: "The rules for the selection [of sponsored dependents] reflect Canada's commitment to the principle of reunion of families. When Canada accepts immigrants, we consider ourselves duty-bound also to accept those close relatives who would normally be dependent on them in a society such as our own" (Department of Manpower and Immigration 1974, 52).

By placing the PGP program within the history of family reunification, it is evident that in Canadian immigration who counts as family and who does not has always been a biopolitical question of the Canadian state. The definition of family is not self-evident or consistent but contested and recast according to the perceived needs of Canada. Our historicization of family unification makes the PGP program reform seem "strange" in the sense that parents and grandparents have not become a problem until recently. Spouses, dependent children, parents and grandparents have consistently been included in the category of Family Class, indicating the political and moral weight associated with their inclusion.

\section{A “PROBLEM OF MATH” AND THE NEOLIBERAL BIOPOLITICAL CONSTRUCTION OF FAMILY}

The legitimacy of including parents and grandparents in Family Class, however, has been fundamentally undermined and their families' claim for reunification 
have been severely and informally circumscribed since the 1990s, and formally restricted by the 2012-2013 regulatory changes, which were driven by an overt concern for the economic cost of the PGP program. As the Canadian Council for Refugees pointed out, a bias that assumed that parents and grandparents are a burden on Canadian society and that their immigration should be decreased was inherent in the government's consultation process (Canadian Council for Refugees 2012). As with previous policy changes, the debate around the PGP program has also taken on a strongly racialized, ethnic undertone. While those opposing the PGP program do not explicitly raise the non-European background of most PGP program applicants as an issue, their concern with elderly people's difficult adjustment is never far from the surface, and reflects their limited understanding of the importance of the elderly in non-European family cultures (Chen 2008). Perhaps due to the Conservative Party's aggressive courting of "ethnic votes," the PGP program was not eliminated outright but was turned into a separate subcategory under the sponsored Family Class, constricted by a number cap, financial qualifications, and regulations regarding how to reunite. Most family reunifications will, from now on, be temporary reunions through Super Visas rather than through permanent immigration.

In this section we examine what is represented as the problem that justified recent changes to PGP program. Math, indeed "very simple" math, has operated as a central trope in immigration policy, giving the impression that sponsored immigration of parents and grandparents is a problem caused by applicants themselves. In the news conference announcing Phase I of the Action Plan, Kenney explained the current backlog as a 'problem of math' thrown onto Canada, saying: "How has this problem developed? It really is very simple. When the number of applications exceeds the number of people admitted to Canada over time, we end up with long and growing backlogs .... Friends, the challenge we're facing is a problem of math, it's also a problem of the heart that families are divided, but the backlog and wait times are a result of math" (CIC 2011a, para 13-14).

By 2011, backlogs grew to a point that more than 165,000 parents and grandparents were waiting for a final decision on their applications. Kenney remarked: "Wait times for Family Class sponsorship applications for parents and grandparents now exceed seven years, and without taking action, those times will continue to grow, and that is unacceptable" (CIC 2011b). When introducing the moratorium and Super Visa, he stressed: "If we do not take real action now, the large and growing backlog in the parents and grandparents program will lead to completely unmanageable wait times" (CIC 2011a).

The infamous backlog, however, was produced directly by the Canadian government. Since the mid-1990s, Canada, under the Liberal Party, had restricted the entry of elderly parents and grandparents by administrative delays and had drastically reduced the proportion of parents and grandparents admitted to Canada, relative to other Family Class groups of immigrants (Chen 2008, 162). Citizenship and Immigration Canada (CIC) justified that the restrictive measures related to parent 
and grandparent immigration, claiming that they reflect a consideration of the value of economic immigrants ${ }^{3}$ and of Canada's strong commitment to "reuniting close family members." By "commitment to reuniting close families," CIC meant "processing spouses, partners, and dependent children on a priority basis" (CIC 2005), and replacing the criterion of dependence, which had been in place since the Immigration Act of 1976 with the criterion of "closeness." The immigration requests for priority category, or so-called "close family members" applicants, were then and continue to be processed "pretty much within a year of the application" (Kenney 2011). In comparison, the processing time for applications to sponsor parents and grandparents took anywhere from three to more than ten years. Even now, there is great disparity between the processing time for PGP program applicants (41 months minimum) and other groups of applicants (ranging from same-day for adopted children to 44 days for spouses, common-law partners and dependent children) (CIC 2014).

In addition to the de-prioritization of parents and grandparents within Family Class, in 2003-2004 Canada imposed a 75 percent reduction in admission quotas for these applicants. Perhaps the most appalling was the intentional administrative delay. As reported by the Canadian Bar Association in 2005, "[For] an eighteen month period from 2003 to 2005 the Case Processing Centre at Mississauga froze the processing of this category of cases. During that period, Citizenship and Immigration Canada continued to receive new applications, and its website still indicated that it would take twenty-one months to process, when not a single application was being processed" (Canadian Bar Association 2005, cited in Chen 2008, 176).

Tracing these discriminatory practices allows us to see that backlogs and unacceptably long wait times did not result from hundreds of thousands of parents and grandparents applications overwhelming the immigration system, but were caused by a combination of restrictive measures and intentional delay tactics. A decade and a half later, the Conservative government attempted to fool the Canadian populace into thinking that the massive backlog was caused by applicants themselves, interestingly shying away from placing the blame on changes made to immigration regulations by the Liberal Party. Even though it was absent from Kenney's speeches, it is not a secret that the kind of math that is really driving the problematization of sponsored parent and grandparent immigration is related to a low birth rate and an aging population in Canada. These broad demographic trends do present Canada's universal health care and social welfare provisions with challenges. Our view is that these should be addressed through reviewing these policies, rather than through singling out a group and denying them family reunification. The shunning and rejection of parent and grandparent migrants echoes the earlier culturally biased discrimination against extended family members in Canadian immigration policy.

Administrative practices of singling out parents and grandparents for adverse treatment have been challenged legally. In 2010 Amir Attaran complained to the

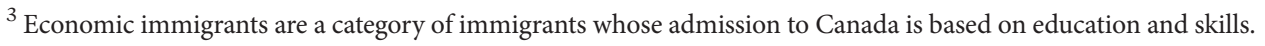


Canadian Human Rights Commission (CHRC), claiming discrimination on the part of CIC. In 2012 the CHRC dismissed his complaint; a federal judge later dismissed his application for judicial review of the decision. However, in 2015 the Federal Court of Appeal found that "CIC was carrying on a discriminatory practice" based on family status by delaying the processing of sponsorship applications for parents and grandparents. The court referred Attaran's complaint about discrimination back to CHRC for reconsideration (Attaran v. Attorney General of Canada; Keung 2015). It is unclear at this point what implications the Federal Court of Appeal's ruling may mean for the revamped PGP program.

Nonetheless, from a sociological perspective, it is clear that adhering to but also reworking the human capital discourse, parents and grandparents, as a group, are perceived by the Canadian government as a human liability Other, burdening society and threatening the quality of life enjoyed by Canadian citizens. Chen (2008) documented examples of the discursive construction of parents and grandparents as undesirable and possibly threatening, such as the assertion of Tom Kent, an eminent Canadian economist, who proposed that Canada needed to "switch the emphasis of immigration policy to youth, to children especially" $(2004,28)$. Picot and Sweetman (2012) proposed a similar refocusing on children and young adults, while Collacott (2002), a commentator associated with the Fraser Institute, blatantly stated that the arrival of large number of parents and grandparents would deplete the Canadian health care system. The recent biopolitical construction of the family has incorporated the factor of age in "the definition of vital properties of a population, the categorization of human beings, and the devising of inclusive and exclusive interventions" (Chen 2008, 183).

Such construction of parents and grandparents as human liabilities has met strong resistance. Sponsor Your Parents, an advocacy group, organized a petition, presented to the House of Commons, in which petitioners articulated the essential but overlooked contributions of parents and grandparents to child care and to community (Chen 2008; VanderPlaat et al. 2009; Leung and McDonald 2001). However, it seems that counter narratives anchored in contributions are important but may also have limitations as inadvertently they validate the human capital discourse, only that they reveal unseen contributions. It is our view that it is also critical to note the biopolitical construction of the ideal immigrant and the resulting discrimination against parents and grandparents on the ground of age and family status. Political theorist Iseult Honohan, in her careful consideration of moral obligations concerning family reunification in migration, contends that there are "critical times" in a family relationship, such as that between adult children and elderly parents, "when the rights and obligations of family relations more urgently require that they be together" $(2009,777)$. In light of this argument, the long delay in processing applications and the most recently introduced stringent terms of reunification runs against the basic human values regarding the importance of family life especially to dependent family members, something that Canada's Green Paper (1974) was explicitly committed to. Indeed, the claim to family reunification, as Honohan argues, "may be considered to rest in the widely held principle that 
family life is a human right, and one embodied in many written documents" (2009, 771). Changes to the PGP program effectively construct overseas parents and grandparents as permanently temporary family members (Rajkumar et al. 2012), who are permitted to reunite with their Canadian families on the condition that their physical and financial strengths are deemed sufficient by the Canadian government.

\section{NEOLIBERAL REGIME OF IMMIGRATION GOVERNANCE}

In this section, we turn to the neoliberal regime of governance that is deployed to manage parents and grandparents as human liabilities, the opposite of human capital. As described earlier, parent and grandparent immigration is currently governed through a host of measures. The Super Visa has been lauded by the Canadian government as "super popular" (CIC 2013a), and has been touted as the "silver bullet" (Keung 2012) for tackling the massive accumulation of PGP program applications. Kenney promoted it as the "the most generous visa provision for temporary resident visas ever in the Canadian immigration system" (ibid.). It is our view that the popularity of the Super Visa among the PGP program applications lies with the simple fact that it permits temporary reunion, which is a better option than continued family separation and endless waiting for permanent immigration application processing. While its multiple entries and length of stay are indeed more favourable relative to other categories of visitor's visas, the essential point that should not be lost is that the Canadian government is substituting a visitor's visa for an immigration visa. As such, it is anything but "super generous." As a regime of governance, the Super Visa and associated immigration measures discriminatorily responsibilize the family, marketize regulation, and maximize the state's control of the border and the population. In what follows we elaborate on some dimensions of the neoliberal immigration governance in Canada, as evinced in the impact of policy changes on citizenship formation and struggles.

\section{Insecurity of Presence}

Family reunification has historically been facilitated through the permanent immigration of the sponsored family member. With the policy changes, a significant portion of parent and grandparent "reunifications" with their families in Canada will be through Super Visas. The Super Visa reinterprets family reunification to mean reunion without immigration and makes family reunification possible under an extended temporary visa. There are two senses of temporariness at work here: first, that the visa is for a temporary term of ten years; second, that the parents must return to their home countries at the end of every two years and the families must apply to have the visa renewed, subject to a medical examination of the applicant and the purchase of private insurance. The requirement of renewing a Super Visa every two years renders family reunification dependent on the health status of elderly family members, family purchasing power, and, no less importantly, on the decision of private insurance companies that are unaccountable to citizens. These produce an "insecurity of presence" (Rajkumar et al. 2012, 484): a presence and life in Canada that is marked by a fear of future inadmissibility to the country, and 
that is without the full range of citizen/resident rights. Seen in this light, the Super Visa creates a new category of exclusion and erects an internal social border in Canadian society (Rajkumar et al. 2012). The outcome of most cases is, at best, a temporary reunification, and at worst, a denial of reunification.

\section{Responsibilizing Families}

The PGP program changes also mean the denial of a range of rights even when a reunification application is approved. Parents and grandparents' rights to social benefits have been the primary concern to the Canadian state under both Liberal and Conservative governments. In the summer of 2011, CIC held nationwide public consultations to determine how important it is to maintain the PGP program and whether this category of Family Class applicants should be given the same application processing priority granted to spouses, conjugal partners, and dependent children. CIC reports that during the consultation period "many concerns were raised about the cost to taxpayers of bringing in older immigrants, in particular health-care costs" (CIC 2011a). In Neborak's view, such discourse "establishes rationale for dissociating application reviews from the lives of real people, creating a process that reduces human life to positive and negative externalities to taxpayers" $(2014,8)$. As we stated earlier, it objectifies parents and grandparents as the opposite of human capital: human liabilities.

For families who manage to become one of the lucky 5,000 applicants accepted for processing each year and who are reunited through an immigration visa, the extension of the sponsorship undertaking period from ten years to twenty years means that families are solely responsible for supporting their parents and grandparents for, essentially, the remainder of the sponsored relatives' lives, regardless of any potential changes to the families' living circumstances. If those families who cannot meet the stringent qualifying criteria of an immigration visa want to reunite they must apply for a Super Visa, and consequently, pay an even higher premium for reunification despite their already lower income. For those who are temporarily reunited through a Super Visa, the "continuous visitor" (rather than "permanent resident") status of the visa holder denies them access to public health care and other social benefits, transferring health care and other potential living expenses to sponsoring families.

\section{RACIALIZED, GENDERED, AND CLASS-BASED INEQUALITIES IN THE RIGHT TO FAMILY LIFE}

The new qualifying criteria for the PGP program make it more difficult for a large segment of families to reunite. While care across generations is common in Canadian family life in general, for many immigrant families such "intergenerational reciprocal care" is especially important not only culturally, but also for reasons of practical family assistance (Leung and McDonald 2001). In light of Honohan's argument, the reformed PGP program negatively affects citizens/denizens who apply to be joined by their families. She observes that “... excluding [parents and] grandparents 
overlooks both the impact on those responsible for their care, and the variety of roles that [parents and] grandparents may play in families. If they are not admitted, it makes it difficult for their families to discharge their duties of care" $(2009,782)$.

Inequalities produced through these policy changes have race-, gender-, and classspecific dimensions. They affect racialized Canadians and disproportionately racialized, elderly women, who comprise a majority of the Family Class immigrants (McLaren and Black 2005; McLaren 2006). Furthermore, the bulk of sponsored parents wishing to be reunited with their children living in Canada are AsiaPacific in origin. Given that immigrants and racialized individuals are faced with higher unemployment rate and more precarious work, and given the persisting inequalities in income (Teelucksingh and Galabuzi 2005; Das Gupta 2006), raising the income threshold for sponsorship applicants effectively produces racialized financial barriers. These changes to the PGP program will exacerbate the economic and social inequalities faced by racialized and immigrant Canadians. We should also note that for those who can afford to apply for the costly Super Visa, the approval rate is higher for US and European countries and substantially lower for countries in Africa, Asia, and the Middle East, where most applicants are from (Ontario Council of Agencies Serving Immigrants 2012; Nerorak 2014).

While it is beyond the scope of this paper to fully explore the relevance of Canada's PGP program reform to the Asia-Pacific region, it is worth mentioning a few implications as possible directions for further investigation. Immigration processes are part of the macro conditions structuring experiences of aging and caregiving (Zhou 2012). For overseas parents and grandparents, the policy changes along with the geographical distance between Canada and the Asia-Pacific present tremendous obstacles to receiving transnational care from their migrated children. Transnational care of elderly relatives is a topic that should receive more attention in studies of migration, transnationalism and care (Ackers 2004; Zechner 2008). The difficulties in providing transnational care may also have an impact on potential immigrants' willingness to come to Canada, especially given that the care of the elderly by children is an important cultural norm in the Asia-Pacific region and because countries in this region do not have an extensive institutional elderly care system.

\section{CONCLUSION}

In this paper we have examined the history of family reunification in the Canadian context. This historicizing exercise unsettles the present sense of inevitability as it makes apparent that the current government is problematizing a group that has, until now, been consistently affirmed as rightful candidates for family reunification. The revamping of the PGP program has been justified by the representation of its deliberate inefficiency (its persistent applications backlog and, the resulting long wait times) as a "problem of math." We have challenged this trope by demonstrating that the backlogs and wait times did not result from excessive numbers of parent and grandparent immigration applications, but was caused by a combination of restrictive measures and intentional delay tactics deployed by 
the Liberal government since the mid-1990s. The PGP program's Super Visa was introduced by the current Conservative government to the supposed application excess problem, permitting short-term, temporary reunification of families in place of permanent immigration. Although the Super Visa has provided some form of relief for immigrant families who have been stuck in the massive backlog for years, along with related measures, it amounts to producing stratified citizenship in the form of inequalities in Canadian citizens' rights to family life and associated social and emotional wellbeing, including the cross-generation functioning of the family. Other than the much smaller group of immigrant families who are lucky enough to successfully sponsor their parents and grandparents' immigration, under the new policy many have to shoulder large expenses if they seek temporary reunification under Super Visa with their parents/grandparents, and many more cannot even have temporary reunification if they do meet the stringent financial and health status criteria of Super Visa. In short, the result is that a group of Canadians are hindered by immigration policy to reunite with their parents/grandparents because of their immigrant status.

Canadian immigration policies in the twenty-first century are intensely focused on aligning the immigration system with the labour market (Fudge and McPhail 2009; Neborak 2014). We have seen drastic shifts in immigration policy in the tightening of restrictions on the eligibility of skilled immigrants, the increasing use of temporary foreign workers, and the delegitimating of elderly parents and grandparents as immigrants. While these changes take different forms, we argue that they constitute a neoliberal regime of immigration governance that responsibilizes the individual and the family, empowers extensive market-based regulation, and maximizes the state's control of the border and the population. In the case of skilled immigrants and temporary foreign workers, what drives these policies is the desire to increase the control that industries and the government have over labour, who to bring in, at what skill level, in which industry, for which regions, at what cost, and for how long. While these policies are concerned with identifying, embracing, channeling, and disposing of the kinds of human capital according to the needs of Canadian corporations, changes to the PGP program seek to discourage, stave off, and lock out human liabilities. Furthermore, it is necessary to recognize how the de-valuation and reduction of human lives to bare economic calculations is significantly racialized, gendered, and class-based.

\section{REFERENCES}

Abu-Laban, Y. and C. Gabriel. 2002. Selling Diversity: Immigration, Multiculturalism, Employment Equity, and Globalization. Peterborough: Broadview Press.

Ackers, L. 2004. "Citizenship, Migration and the Valuation of Care in the European Union." Journal of Ethnic and Migration Studies. 30 (2): 373-396. 
Alboim, Naomi, and Karen Cohl. 2012. Shaping the Future: Canada's Rapidly Changing Immigration Policies. Toronto: Maytree.

Attaran, A. v. Attoney General of Canada, Federal Court of Appeal Canada. http://decisions.fca-caf.gc.ca/fca-caf/decisions/en/item/107769/index.do. Accessed March 4, 2015.

Bacchi, Carol. 2009. Analyzing Policy: What's the Problem Represented to Be? Frenchs Forest, NSW: Pearson Education.

—. 2012. "Why Study Problematizations? Making Politics Visible." Open Journal of Political Science. 2 (1): 1-8.

Boyd, Monica. 2014. "Recruiting High Skill Labour in North America: Policies, Outcomes and Futures." International Migration. 52 (3): 40-54.

Boyd, Monica and Naomi Alboim. 2012. "Managing International Migration: The Canadian Case." In Dan Rodríguez-García ed. Managing Immigration and Diversity in Canada: A Transatlantic Dialogue in the New Age of Migration. Montreal and Kingston: McGill-Queen's University Press, 119-146.

Canadian Council for Refugees. 2012. "CCR Backgrounder: CIC Consultations on the Parent and Grandparent Program.” http://ccrweb.ca. Accessed April 22, 2013.

Chen, Xiaobei. 2008. “The Child-Citizen.” In Engin F. Isin et al. eds. Recasting the Social in Citizenship, Toronto; Buffalo; London: University of Toronto Press, 162-186.

Collacott, Martin. 2002. "Canada's Immigration Policy: The Need for Major Reform." Vancouver: Fraser Institute.

Citizenship and Immigration Canada (CIC). 2004. "Formal letter sent to people who submitted the application to Sponsor a Member of the Family Class." Ottawa: CIC.

2011a, November 4. "Speaking Notes for The Hon. Jason Kenney, P.C., M.P. Minister of Citizenship, Immigration and Multiculturalism" at a news conference to announce measures to cut the backlog and wait times for family reunification. Mississauga.

. 2011b, November 4. "News Release: Government of Canada to Cut Backlog and Wait Times for Family Reunification, Phase I of Action Plan for Faster Family Reunification."

—. 2011c, December 19. "News Release: First Parent and Grandparent Super Visa Issued Two Weeks after Launch."

—_. 2012, March 25. "Transforming the Immigration System: Then and Now." 
—_. 2013a, March 6. "News Release: Super Visa is Super Popular, Over 15,000 Parent and Grandparent Super Visas Issued."

—.2013b, May 17. "Backgrounder — Action Plan for Faster Family Reunification: Phase II."

—_. 2014. "Processing Times: Family Sponsorship."

—_. 2015. "Citizenship and Immigration Canada Facts and Figures 2013."

ComeFromChina.com. 2005, February 26. http://bbs.comefromchina.com/ forum5/. Accessed February 26, 2015.

Das Gupta, Tania. 2006. "Racism/Anti-racism, Precarious Employment, and Unions.” In Leah F. Vosko ed. Precarious Employment: Understanding Labour Market Insecurity in Canada. Montreal: McGill-Queen University Press, 318-334.

Department of Manpower and Immigration Canada. 1966. "Canadian Immigration Policy: White Paper on Immigration."

1974. "Immigration Program: Green Paper on Immigration" Vol. 2. Ottawa: Information Canada.

Dean, Mitchell. 2014. "Rethinking Neoliberalism." Journal of Sociology. 50 (2): 150-163.

DeShaw, Rell. 2006. "The History of Family Reunification in Canada and Current Policy." Canadian Issues. 9.

Daniel, Dominique. 2005. "The Debate on Family Reunification and Canada's Immigration Act of 1976." American Review of Canadian Studies. 35 (4): 683-703.

Foucault, Michel. 2003. Society Must be Defended: Lectures at the Collège de France, 1975-76. David Macey, trans. New York: Picador.

Fudge, Judy, and Fiona MacPhail. 2009. "The Temporary Foreign Worker Program in Canada: Low-Skilled Workers as an Extreme Form of Flexible Labor." Comparative Labor Law \& Policy Journal. 31 (1): 5-45.

Government of Canada. 2001. Immigration and Refugee Protection Act. http://laws-lois.justice.gc.ca/eng/acts/I-2.5/20120815/P1TT3xt3.html. Accessed February 15, 2015.

Hawkins, Freda. 1972. Canada and Immigration: Public Policy and Public Concerns. Montreal and London: McGill-Queen's University Press.

House of Commons Standing Committee on Labour, Manpower and Immigration. Minutes of Proceedings and Evidence. June 16, 1977. 37:19. 
Honohan, Iseult. 2009. "Reconsidering the Claim to Family Reunification in Migration.” Political Studies. 57: 768-787.

House of Commons Standing Committee on Immigration and Citizenship. 2012. "Cutting the Queue: Reducing Canada's Immigration Backlogs and Wait Times." Ottawa: Public Works and Government Services Canada.

Kenney, Jason. 2011. Minister of Citizenship, Immigration and multiculturalism. House of Commons Standing Committee on Citizenship and Immigration. House of Commons Debates. October 20.

Kent, Tom. 2004. "In the National Interest: A Social Policy Agenda for a New Century, Restore Cooperative Federalism, Modernize Medicare, Put Children First." Policy Options. (Aug.): 24-9.

Keung, Nicholas. 2012, March 14. "Super Visa applications for visitors to Canada are often rejected.” Toronto Star. www.thestar.com. Accessed February 9, 2015.

—. 2015, February 6. "Immigration Program for Parents ‘Discriminatory,' Federal Court of Appeal Rules.” Toronto Star. www.thestar.com. Accessed February 9, 2015.

Leung, H.H. and MacDonald, L. 2001. Chinese Immigrant Women Who Care for Ageing Parents. Toronto: CERIS and Chinese Canadian National Council.

Ley, D., and D. Hiebert. 2001. "Immigration Policy as Population Policy." Canadian Geographer - Geographe Canadien 45 (1): 120-125.

Li, P. 2003. Destination Canada: Immigration Debates and Issues. Toronto: Oxford University Press.

. 2004. "The Place of Immigrants: Politics of Difference in Territorial and Social Space.” Canadian Diversity. 3 (2): 23-8.

McLaren, A. T. 2006. "Parental Sponsorship - Whose Problematic? A Consideration of South Asian Women's Immigration Experiences in Vancouver." In Research on Immigration and Integration in the Metropolis. Vancouver Centre of Excellence. Working Paper Series, 06-08.

McLaren, A. T. and T. L. Black. 2005. "Family Class and Immigration in Canada: Implications for Sponsored Elderly Women." Research on Immigration and Integration in the Metropolis. Vancouver Centre of Excellence. Working Paper Series, 05-26.

Neborak, Jacklyn. 2014. "Family Reunification?: A Critical Analysis of Citizenship and Immigration Canada's 2013 Reforms to the Family Class." Ryerson Centre for Immigration and Settlement Working Paper No.2013/8.

Ontario Council of Agencies Serving Immigrants. 2012. Sponsoring Parents and Grandparents: Is Canada failing to reunify families? 
Panusa, Gianpaolo. 2012, December. "Update on Parent and Grandparent Sponsorship." http://immigrationcanada.pro/immigrate/update-on-parent-andgrandparent-sponsorship/. Accessed April 24, 2013.

Picot, Garnett, and Arthur Sweetman. 2012. Making it in Canada: Immigration Outcomes and Policies. Montreal: Institute for Research on Public Policy, 2012.

Rajkumar, Deepa, Laurel Berkowitz, Leah F. Vosko, Valerie Preston and Robert Latham. 2012. "At the Temporary-Permanent Divide: How Canada Produces Temporariness and Makes Citizens Through Its Security, Work, and Settlement Policies." Citizenship Studies. 16 (3-4): 483-510.

St. John-Jones, L. W. 1973. "Canadian Immigration: Policy and Trends in the 1960s" International Migration. 11 (4): 141-170.

Teelucksingh, Cheryl and Grace-Edward Galabuzi. 2005. "Working Precariously: The Impact of Race and Immigrant Status on Employment Opportunities and Outcomes in Canada." Policy Matters. 22, 1-11.

VanderPlaat, Madine, Howard Ramos and Yoko Yoshida. 2009. "A Preliminary Investigation of the Contributions of Sponsored Parents and Grandparents in Canada.” Atlantic Metropolis Centre Working Paper Series.

Walters, William. 2002. "Mapping Schengenland: Denaturalizing the Border" Environment and Planning D: Society and Space. 20: 561-580.

Zhou, Yanqiu Rachel. 2012. "Space, Time, and Self: Rethinking Aging in the Contexts of Immigration and Transnationalism." Journal of Aging Studies. 26: 232242.

Zechner, Minna. 2008. "Care of Older Persons in Transnational Settings." Journal of Aging Studies. 22: 32-44. 